Article

\title{
Durability and Reliability of EV Batteries under Electric Utility Grid Operations: Impact of Frequency Regulation Usage on Cell Degradation
}

\author{
George Baure and Matthieu Dubarry*iD \\ Hawai'i Natural Energy Institute, SOEST, University of Hawai'i at Mānoa, 1680 East-West Road, POST 109, \\ Honolulu, HI 96822, USA; gbaure@hawaii.edu \\ * Correspondence: matthieu@hawaii.edu; Tel.: +1-808-9562349
}

Received: 31 March 2020; Accepted: 13 May 2020; Published: 15 May 2020

check for updates

\begin{abstract}
The usage of electric vehicle batteries to assist the main electric grid for the storage of energy provided by intermittent sources should become an essential tool to increase the penetration of green energies. However, this service induces additional usage on the cells and, therefore, could degrade them further. Since degradation is path-dependent, it is of paramount importance to test the impact of all the different grid applications on the batteries. In this work, we tested the additional usage induced by using electric vehicle batteries for frequency regulation at moderate rates during rest or charge and found no detrimental effect after around 2000 cycles on the cells.
\end{abstract}

Keywords: lithium-ion; $\mathrm{dQ} / \mathrm{dV} ; \mathrm{dV} / \mathrm{dQ}$; frequency regulation; $\mathrm{V} 2 \mathrm{G} ; \mathrm{G} 2 \mathrm{~V}$; electric vehicle

\section{Introduction}

The Hawai'i Clean Energy Initiative endeavors to gain total oil independence by 2045 [1] for both electricity generation and ground transportation. On the grid side, the energy portfolio will likely include many intermittent resources such as wind and solar and will thus require significant energy storage. The electrification of ground transportation could kill two birds with one stone by providing oil-free vehicles and offer energy storage when the vehicles are not in use. The latter is referred to as vehicle-to-grid (V2G) and grid-to-vehicle (G2V).

With incentives in place [2,3], the number of electric vehicles (EVs) in Hawai'i and the rest of the world continues to rise and will collectively constitute a significant distributed energy storage reservoir for the grid. EV batteries could provide ancillary grid services such as operating reserves, power curtailment, frequency regulation, and voltage smoothing by allowing the network to give $(\mathrm{G} 2 \mathrm{~V})$ and take $(\mathrm{V} 2 \mathrm{G})$ energy when necessary $[4,5]$. The benefits and drawbacks to both the vehicle owner and the energy provider of these strategies have been well-documented [6-18], and the main obstacle was identified to be the additional usage on the cells [19-21], among other challenges [22]. Few experimental studies [23-28] attempted to account for the change in battery degradation resulting from the implementation of these strategies. To accurately account for the change in usage, the path dependence of degradation needs to be considered in the estimation [29]. Each of these ancillary grid services can affect degradation differently, and certain conditions can lead to accelerated capacity loss [30-32]. This accelerated capacity loss, sometimes termed "rollover failure" [33], is a significant safety concern to the battery industry. However, solutions do exist, and it was shown in a previous work [31] that, although this second stage of degradation cannot be predicted from capacity nor the resistance evolution, it might be predicted from the investigation of the voltage response using electrochemical voltage spectroscopies $[29,34,35]$.

This work is a follow-up of our previous studies $[25,26,36,37]$, in which we purchased a batch of commercial cells to test the impact of different aspects of EV battery usage. Part 1 was devoted to 
the definition of the cell-to-cell variations of the full batch and the emulation of the electrochemical behavior [36]. Part 2 focused on the capacity- and resistance-based analyses of cycle- and calendar-aging experiments to assess the impact of bidirectional charging durability [25]. In Part 3, [26], the cycle and calendar-aging degradation mechanisms were investigated using an incremental capacity analysis and the features of interest (FOI) approach [38]. The analysis was used to quantify the different degradation modes, determine the degradation path dependency, and challenge the Part 2 [25] capacity- and resistance-based forecast. Finally, Part 4 was devoted to the study of the impact of different driving cycles on the degradation mechanisms [37].

The next step of this EV battery degradation research, detailed here, is quantifying the consequences of a distinct grid interaction: frequency response. This investigation elucidates the impact of frequency regulation under several conditions, including a new approach of modulating the charge so that the vehicle can perform grid applications without any additional battery usage.

\section{Materials and Methods}

In this work, a set of twelve Panasonic cylindrical 3350 mAh NCR 18650B batteries were selected from a batch of 100. More details on these cylindrical 18650-size graphite/ $\mathrm{LiNi}_{\mathrm{x}} \mathrm{Co}_{1-\mathrm{x}-\mathrm{y}} \mathrm{Al}_{\mathrm{y}} \mathrm{O}_{2}(\mathrm{NCA})$ cells, as well as the batch cell-to-cell variations analysis, can be found in previous works $[25,26,36,37]$. These cells are similar with the type of cells used in some EVs, such as the Tesla Model S [39,40]. The twelve cells chosen were within the outlier boundaries of the cell-to-cell variations distribution [36]. The experimental design for this study consisted of six test scenarios, with common conditioning and reference performance tests (RPT) [41], replicated twice.

As described in previous publications [36,41], all cells were subjected to initial conditioning and characterization tests before the beginning of the cycling experiment to verify the quality of cells. Following the conditioning cycles at $\mathrm{C} / 5$ and $\mathrm{C} / 2$, and before the start of the duty cycle testing, an RPT consisting of $\mathrm{C} / 35, \mathrm{C} / 5$, and $\mathrm{C} / 3$ full cycles was performed on all cells. The RPT procedure included some remnant capacity measurements consisting of a C/50 top-off at the end of each regime, as well as 4 -h rests before and after the remnant capacity measurements. The rate capability was calculated by dividing the $\mathrm{C} / 3$ capacity by the $\mathrm{C} / 25$ capacity at each RPT. The resistance was derived from the ohmic drop associated with the transition from a resting stage to a $C / 3$ rate [41] $0.1 \mathrm{~s}$ after the application of current.

Each duty cycle began with a $\mathrm{C} / 2$ full charge, as well as a constant voltage step with a $65-\mathrm{mA}$ limiting current followed by a 4 -h rest step. The cells were then discharged by around $60 \%$ of their typical initial capacity by applying the United States Advanced Battery Consortium (USABC) federal urban driving schedule (FUDS) power profile [3] and scaled to the USABC goal of $400 \mathrm{~W} / \mathrm{kg}$. The FUDS profile was shown to replicate driving cell degradation adequately [37]. This usage equated to about three hours of driving per day or about 3 times the typical American roundtrip commute, according to the U.S. Census Bureau. After the discharge, the cells were first rested for half an hour. Subsequently, the cells were subjected to six different scenarios (Figure 1).

In the first scenario (NoFR), no frequency regulation was applied (Figure 1a,b), and the cells rested for $4 \mathrm{~h}$ before being charged at a $\mathrm{C} / 4$ rate then by a constant-voltage step with a 65-mA limiting current followed by a half-hour relaxation. In scenarios two to four, the cells were used for frequency regulation for $2 \mathrm{~h}$ during rest (Figure 1, right column). The frequency regulation profile was extracted from representative real usage data from a grid-scale battery energy storage system located in Hawi, Hawai'i while in frequency regulation mode [42-44] (Figure S1). This frequency regulation profile was normalized to three different maximum currents corresponding to $C / 5$ (Figure 1c, frequency rest (FRr)C/5), C/4 (Figure 1d, $\mathrm{FRrC} / 4$ ), and $\mathrm{C} / 3$ (Figure 1e, $\mathrm{FRrC} / 3$ ) rates, but the pulses variations and the depth of the discharge range were kept constant to stay within cell and testing channel availability constraints. The additional usage of the cells added $0.28 \mathrm{Ah}(+8.6 \%), 0.35 \mathrm{Ah}(+10.7 \%)$, and $0.47 \mathrm{Ah}$ $(+14.3 \%)$ of exchanged capacity per cycle, respectively. After the $2-\mathrm{h}$ frequency regulation, the cells were rested for an additional one and a half hours, then charged at $\mathrm{C} / 4$ followed by a constant-voltage 
step with a 65-mA-limiting current and a half-hour rest step. In scenarios five and six, the cells were subjected to the same frequency regulation profile, this time added to the $\mathrm{C} / 4$ charge instead of during rest (Figure 1f,g). In these two cases, the cells rested for $4 \mathrm{~h}$ before being subjected to the amalgamation of the frequency regulation profile and the $\mathrm{C} / 4$ charge for $2 \mathrm{~h}$. The frequency regulation was only normalized to two different maximum currents: $C / 5$ (Figure $1 \mathrm{f}$, frequency charge (FRc) $C / 5$ ) and $C / 4$ (Figure 1g, FRcC/4), so that the current never becomes negative (i.e., discharging) during charge. Since the charge current was always positive while modulated, no additional capacity was exchanged for scenarios five and six compared to not performing the frequency regulation at all. After the frequency regulation, the cells were topped with a charged at $\mathrm{C} / 4$ followed by a constant-voltage step with a 65-mA-limiting current and a half-hour rest.
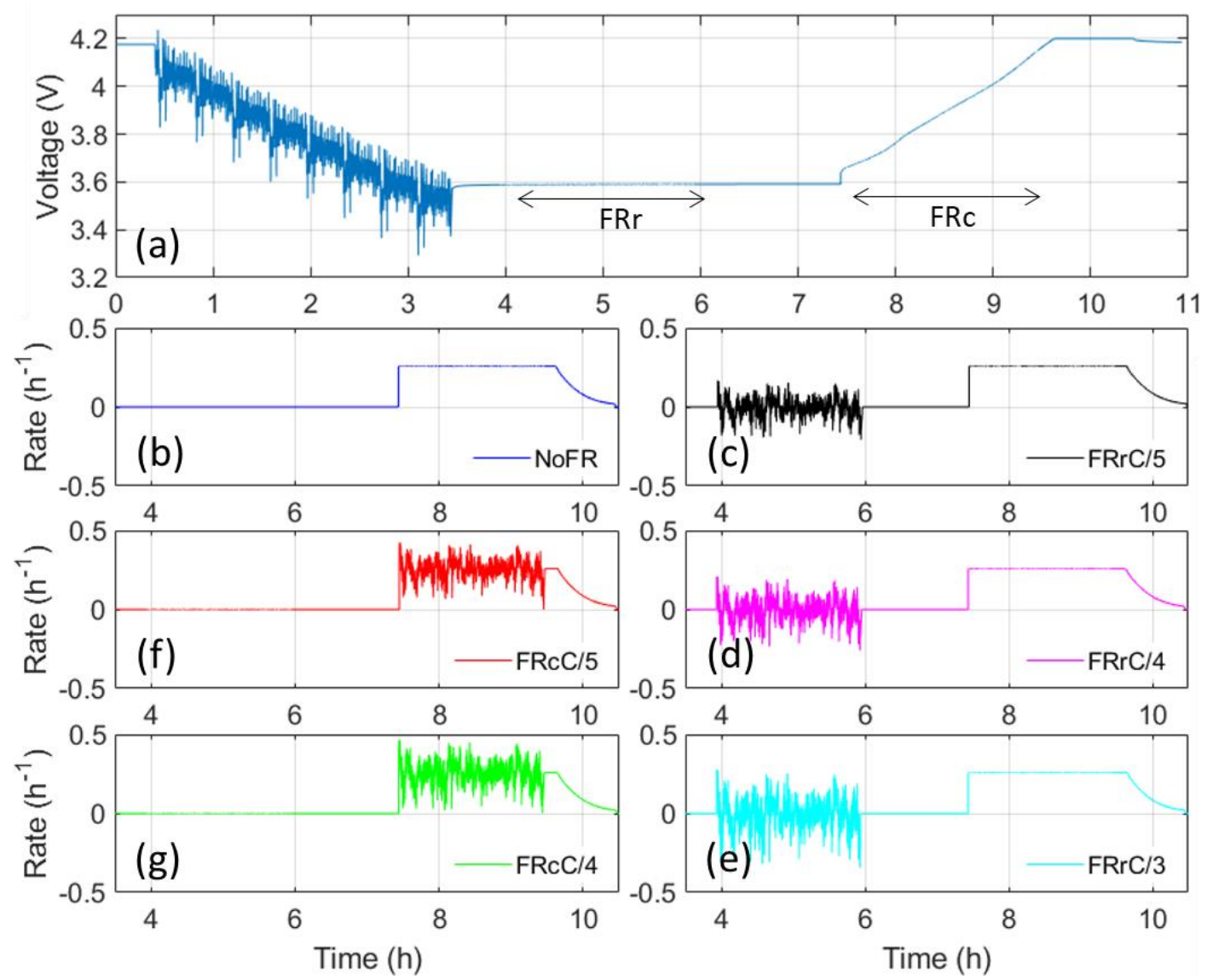

Figure 1. (a) Full duty cycle and (b-g) charge scenarios for the six duty cycles. noFR: no frequency regulation, FRc: frequency response during charge, and FRr: frequency regulation during rest.

These six duty cycles were typically repeated for four weeks; after which, an RPT was performed. Cycling was interrupted when the cell exhibited a capacity loss of greater than $20 \%$ at C/35 for two consecutive RPTs or when the total test time was approximately two years. All the tests were performed in an Amerex IC500-R chamber set at $25^{\circ} \mathrm{C}$. The skin temperature of each of the cells was recorded and was of $24.5 \pm 0.5^{\circ} \mathrm{C}$ in average. The cut-off voltages were set at 4.2 and $2.5 \mathrm{~V}$. All the tests, except the first RPTs for each cell, were performed by a 40-channel Arbin BT-5HC tester (College Station, TX, USA). The first RPTs were performed using a Biologic BCS-815 battery cycler (Claix, France).

Computer simulations were performed using the mechanistic degradation model proposed in [45] and the 'alawa toolbox. The half-cell data was obtained from previous works $[25,26,36,37]$. 


\section{Results}

Figure 2 plots the normalized capacity (top), normalized resistance (center), and rate capability (bottom) versus exchanged capacity for the twelve cells used in this study. All the cells presented a similar linear $\left(R^{2}>0.93\right)$ capacity loss for close to 5000 Ah exchanged (1500 equivalent full cycles) at a rate of $-0.0024 \% \pm 0.0004 \%$ per Ah of exchanged capacity. All but one of the cells exchanged more than 6500 Ah (2000 equivalent full cycles), with capacity losses below 20\%. This is a much smaller capacity fade than in our previous work on full discharges [37] but comparable to the one using shallower cycles $[25,26]$. The most apparent result was that the cells subjected to no frequency regulation (NoFR) degraded slightly faster. These two cells exhibited two of the three highest capacity loss values of the entire experiment: 35\% and 17\%. In addition, one of these cells (NoFR_1) experienced an accelerated aging stage much earlier than all the others after an exchanged capacity of $4700 \mathrm{Ah}$ and a normalized capacity of $88 \%$. In total, four cells reached a second aging stage defined with more than a $5 \%$ loss within an exchanged capacity of $600 \mathrm{Ah}$. The other three cells that experienced accelerated aging were the second NoFR cell and one each for the cells with the frequency regulation during charge and rest (FRcC/4_1 and FRrC/5_2). These three cells entered the second stage after 5500 Ah of usage. No abnormality in the testing protocol of the affected cells was noticed, and their initial cell-to-cell variations were within the normal boundaries. It can also be observed from Figure 2 that neither resistance nor rate capability could be used to predict the accelerated degradation. The resistance increased linearly and doubled after around 3500 Ah exchanged. The rate capability slowly deceased, also linearly, by less than $1 \%$.

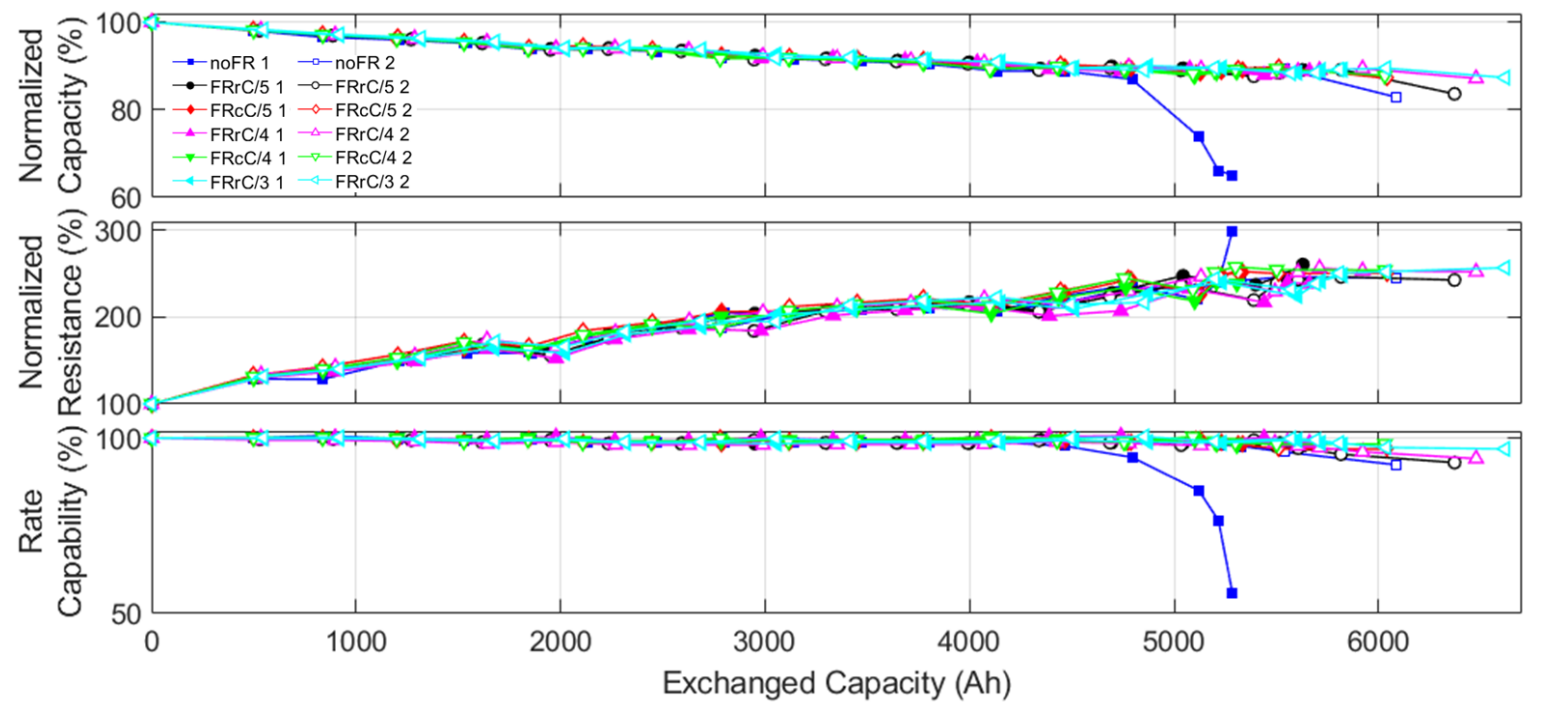

Figure 2. Normalized capacity, resistance, and rate capability versus exchanged capacity.

As discussed in our previous work, capacity loss and degradation must be considered separately as silent degradation (i.e., degradation that was not associated with capacity loss) can be present and play a significant role in the apparition of the accelerated aging phase $[29,45]$. To assess cell degradations, it was essential to quantify the degradation modes, the loss of lithium inventory, the loss of active material, and the kinetic degradation (RDF) on the positive (PE) and negative (NE) electrodes independently. This separation of the degradation modes can be performed using electrochemical voltage spectroscopies [46], incremental capacity (IC) [35,47], and differential voltage (DV) $[34,48,49]$. In our previous work on these cells [26,37], we used IC curves to quantify the loss of

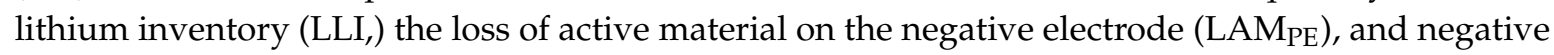
kinetic degradation $\left(\mathrm{RDF}_{\mathrm{NE}}\right)$ directly from the FOIs but had to quantify the LAM $\mathrm{NE}_{\mathrm{N}}$ manually based on the other observations. In this analysis, the technique was refined, and the LAM $\mathrm{NE}_{\mathrm{NE}}$ was quantified from the FOI on the DV curves when possible. Figure 3 presents an example of the IC and DV curves 
for a representative cell with the different FOIs noted. The response for all the cells is remarkably similar and is presented in Figures S2 and S3.
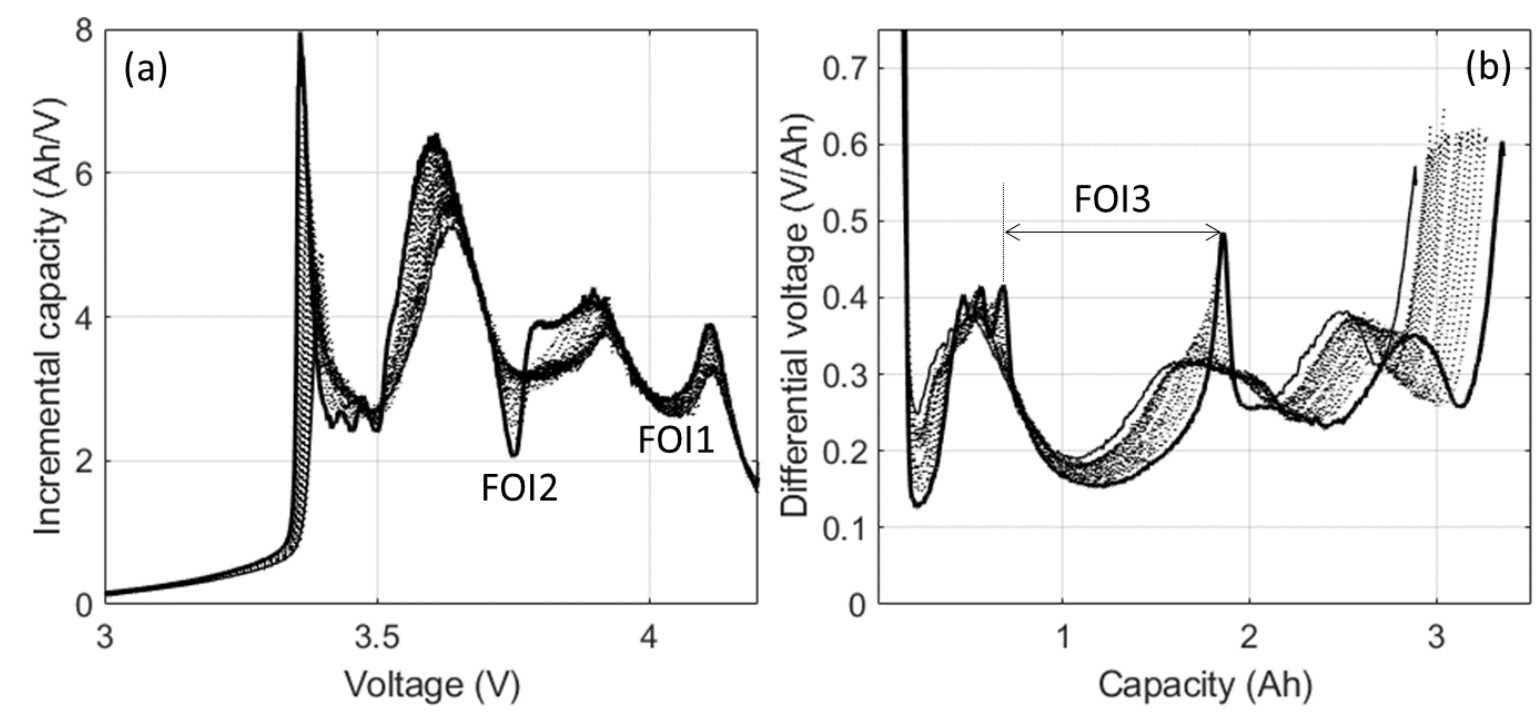

Figure 3. Representative (a) incremental capacity and (b) differential voltage curve evolutions at C/35 under the aging conditions tested. FOI: features of interest.

Just as in our previous work, and based on the degradation map in $[29,45]$ and the evolution of the experimental curves, the capacity loss was associated entirely to LLI because the high and low-voltage peaks never disappeared completely. Moreover, the intensity of the minimum at $4 \mathrm{~V}$ is proportional to the $\mathrm{LAM}_{\mathrm{PE}}$, and the intensity of the minimum at $3.75 \mathrm{~V}$ is proportional to the RDF $\mathrm{NE}$. Readers are referred to these publications for more details. To quantify the $\mathrm{LAM}_{\mathrm{NE}}$ automatically, the distance between two graphitic peaks was used as a proxy to the $\mathrm{LAM}_{\mathrm{NE}}$, as proposed in $[48,50]$. The full degradation map for the DV curves showing that the distance between the two peaks varies only for the $\mathrm{LAM}_{\mathrm{NE}}$ is presented in Figure S4.

Figure 4 presents the evolution of the different FOIs upon aging. Figure 4a shows the evolution of FOI1; the area between 4 and $4.05 \mathrm{~V}$ was used in lieu of the intensity at $4 \mathrm{~V}$ to minimize the impact of noise on the voltage data. All the cells followed a similar deviation to the pristine behavior, with a decrease comprised between $5 \%$ and $6 \%$. In regards to FOI2, as already observed in our previous work $[29,45]$, the evolution of the intensity saturates after the local minimum completely disappeared. This saturation prevented the tracking of further intensity rise and the position of the minimum, (Figure 4c). The variation in the intensity of the minimum is consistent with what was observed in our previous work, but its voltage seems to be rather constant for all cells, which is different from what was found previously $[29,45]$, for some of the tested conditions. Finally, FOI3 (Figure 4d) decreased linearly by between $6 \%$ and $10 \%$ before the 4000 Ah mark. After that, the peaks disappeared on the DV curves, and the direct estimator was not valid anymore. This change was likely induced by the RDF $\mathrm{NE}$ increase (Figure S4).

The quantification of the degradation modes from the FOI variations can be done using the mechanistic modeling approach we pioneered, along with other groups, in the mid-2000s [45,48,51,52]. The approach has been heavily used in recent years within experimental studies using electrochemical voltage spectroscopies (EVS) [46,53], and it has been well-validated [54-56] using independent experimental studies. In the approach, half-cell data from each electrode is matched to emulate the electrochemical behavior of the full cells. Once the initial match is satisfactory, the electrode can be scaled or translated individually to replicate the effect of the different degradation modes [45]. The electrode matching and the voltage changes associated with degradation for these cells have already been heavily discussed in the literature $[26,36,37]$ and will not be repeated here. As in our previous work [26,37], the theoretical variations for the FOIs for each individual degradation 
mode was computed and compared to the experimental variations to decipher the extent of each degradation mode.
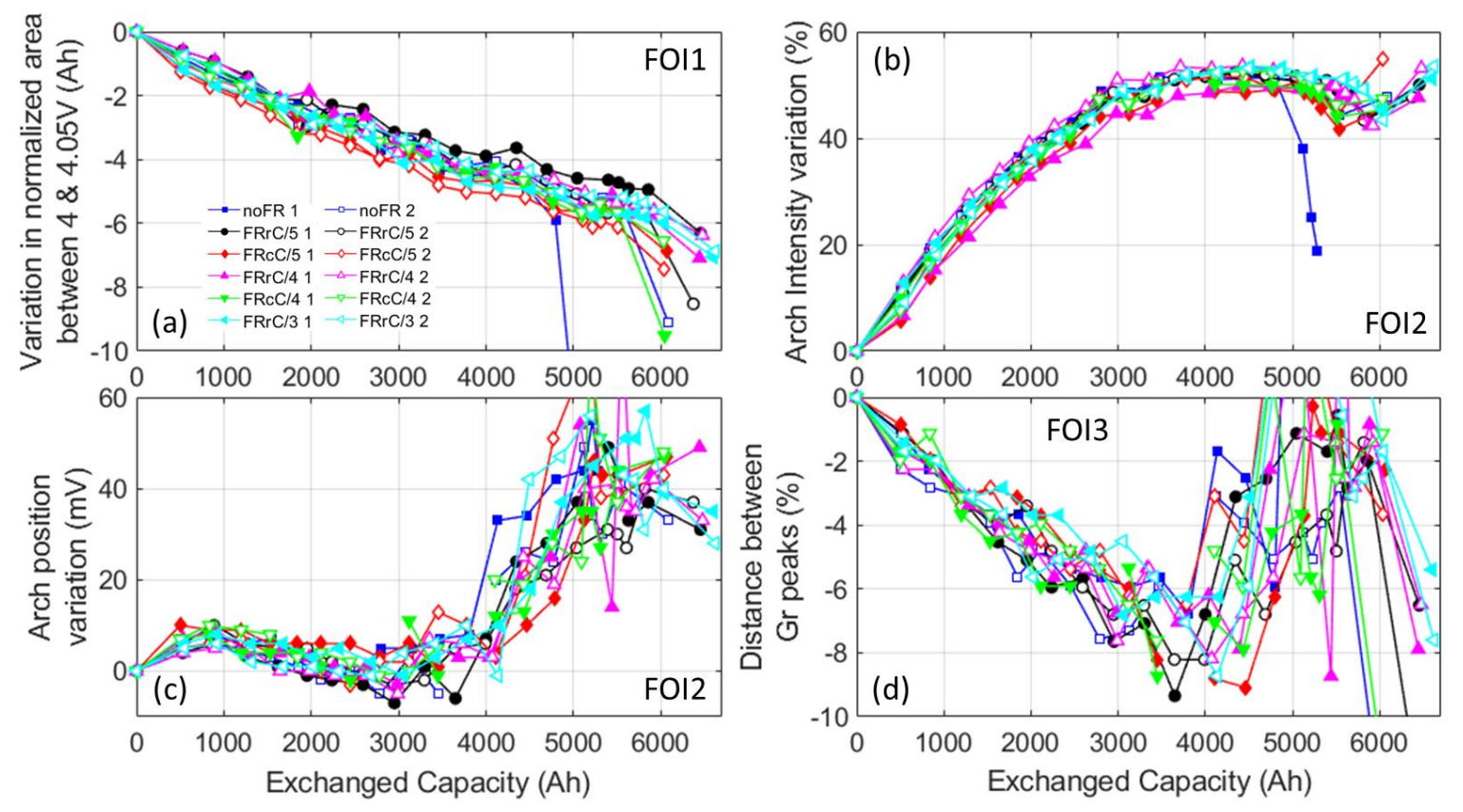

Figure 4. Evolution of (a) FOI1, the (b) intensity and (c) position of FOI2, and (d) FOI3.

\section{Discussion}

Based on Figure 4 and the proportionality between the FOI variations and the main degradation modes, the degradation of the cell up to 3000 Ah can be automatically deciphered using the same strategy that we employed in our previous works $[29,45]$ and the fact that the cells had minimal initial cell-to-cell variations [36]. The results of the analysis are presented in Figure 5. The spider plot in Figure 5a showcases the results of the automatic quantification of the four main degradation modes (LLI, LAM $\mathrm{PE}, \mathrm{LAM}_{\mathrm{NE}}$, and $\mathrm{RDF}_{\mathrm{NE}}$ ). After $3000 \mathrm{Ah}$, the cells lost between $7 \%$ and $8 \%$ of their lithium, $5 \%$ and $8 \%$ of the NE, and $3 \%$ and $4.5 \%$ of their PE and their kinetics degraded by a factor comprised between 7 and 8 . Overall, as already observable from Figure S2, all the cells degraded in a similar fashion, and no apparent differences were observed between the cells that reached the second stage earlier than the others. Figure $5 b$ displays the same data on a bar plot to elucidate the impact, if any, of the duty cycles. The plotted values are the average between the two cells tested for each condition, and the error bars represent the spread between the individual values. Comparing the six cells that undertook the frequency regulation at different rates during rest ( $3 \mathrm{FRr} \times 2)$, the spread of values was similar or smaller than the deviations between cells undergoing the same duty cycles. This is true for the other duty cycles as well. Taking into account the fact that cells under the same duty cycle are well-known to degrade at slightly different paces [57-60], the differences observed in this work are not big enough to conclude that six duty cycles tested in this work induced different degradation on the cells. The spider plot can also be compared to the ones in our previous work that tested the cells under different duty cycles [29,45]. In [26], we diagnosed the cells after a 5\% capacity loss, which corresponded to 1500 Ah exchanged in our study. For the duty cycles in this work, we observed a degradation similar to one of the cells that did not experience any constant power (V2G). This outcome was expected, since the duty cycle resembled the NoFR duty cycle, with just a different driving cycle (RD1 in [37]), which we showed had a similar impact as the FUDS cycle used in this work [37]. In [37], where they cycled the cells in the full state of charge (SOC) range, the spider plot compared the degradation at the onset of stage 2 around the same capacity loss (except for RD2 
in [37]). All degradation modes are in the same order of magnitude except $\mathrm{LAM}_{\mathrm{NE}}$, which was much more pronounced when the full SOC range was used.
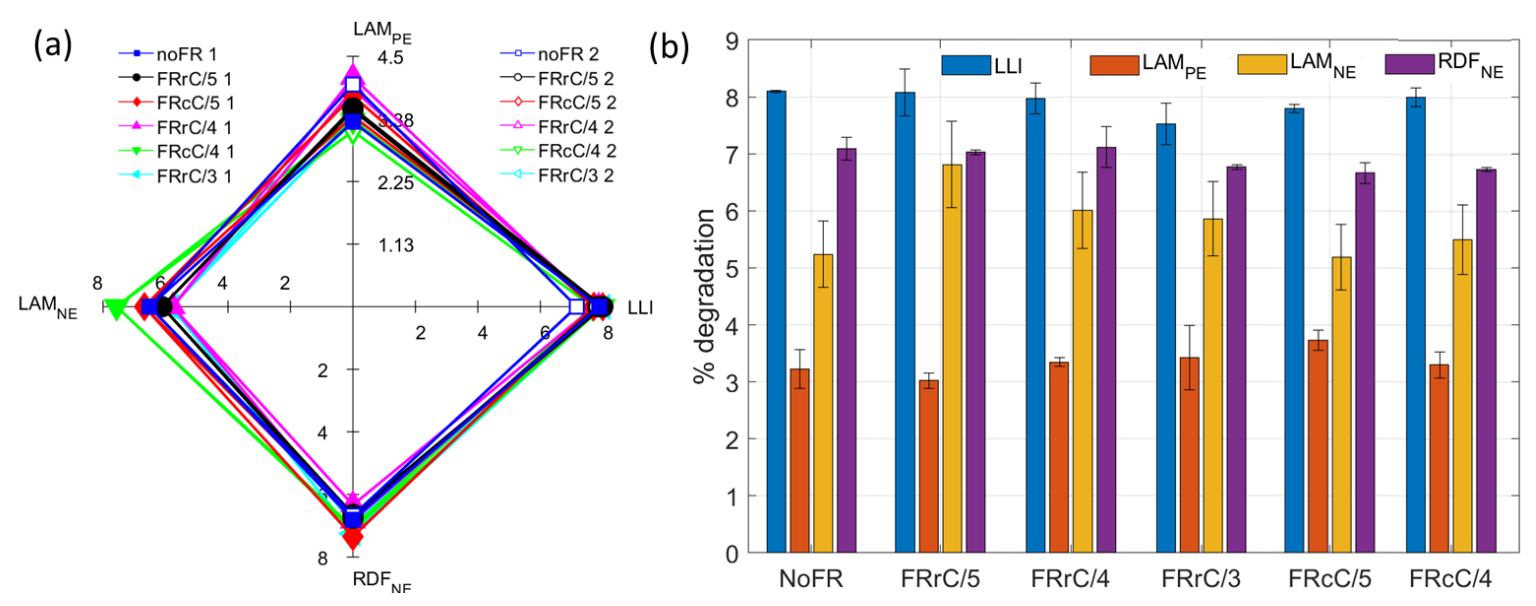

Figure 5. (a) Spider plots of the four prominent degradation modes for all the cells at $3000 \mathrm{Ah}$ ( $~ 8 \%$ capacity loss) and (b) bar plot showcasing the impact of the duty cycles. The error bar represents the spread between the two tested cells for each duty cycle, not a distribution of values. LLI: loss of lithium inventory, LAM: loss of active material on the positive (PE) and negative (NE) electrodes, and $\mathrm{RDF}_{\mathrm{NE}}$ : rate degradation factor on the NE.

Figure 6a presents a validation of the automatic diagnosis performed for Figure 5 for cell NoFR_1. This is important to verify that the automatic quantification of the degradation was correct. If accurate, the changes induced on the electrode half-cell matching by the quantified amount of LLI, LAMs, and RDF should replicate the observed voltage changes between the initial and the aged experimental voltage response. The simulated voltage was nearly overlapping to the experimental one, and this suggests that our automatic quantification of the degradation mode was appropriate, as any other combination of parameters would have led to a different voltage curve. The validation was verified for all the other cells. Since the simulated response was analogous to the experimental one [46], the diagnosis was validated. Hence, our automatic FOI-based methodology managed to perform the diagnosis automatically.

The next point to tackle is the observed differences at which the second stage is appearing. In previous works on similar cells, the second stage apparition was proved to be linked to the $\mathrm{LAM}_{\mathrm{NE}}$ [37]. It was shown that when the $\mathrm{LAM}_{\mathrm{NE}}$ reached a threshold, decipherable from the initial conditions and the LLI and LAM ${ }_{\mathrm{PE}}$, lithium plating began. Since the LLI and LAM $\mathrm{PE}_{\text {were }}$ quantifiable for the entire experiment, the predicted $L_{A M}$ necessary for generalized plating to occur was calculated to be around $20 \%$ for cell NoFR_1 when the second stage started. However, quantification showed the $\mathrm{LAM}_{\mathrm{NE}}$ around $11 \%$. This value was lower than the amount of LLI and in good agreement with an extrapolation of the linear trend of $\mathrm{LAM}_{\mathrm{NE}}$ from the early cycles. The same trend was verified for the other cells that showcased the second stage. Therefore, and unlike our previous study, the second stage of degradation was not induced by a generalized $\mathrm{LAM}_{\mathrm{NE}}$. It was also not induced by the $\mathrm{LAM}_{\mathrm{PE}}$. This rule out any electrode-wide source for the second stage. A possible explanation is that it might still happen locally because of inhomogeneities in the electrode degradation [61]. The origin of the apparent RDF increase is still unclear. In our approach, it was treated as a kinetic limitation, but, in light of recent literature [62], part of it could also be associated with inhomogeneities in the electrode degradation that could have led to localized plating. This concept is currently under investigation in our laboratory and will be reported in future works. 

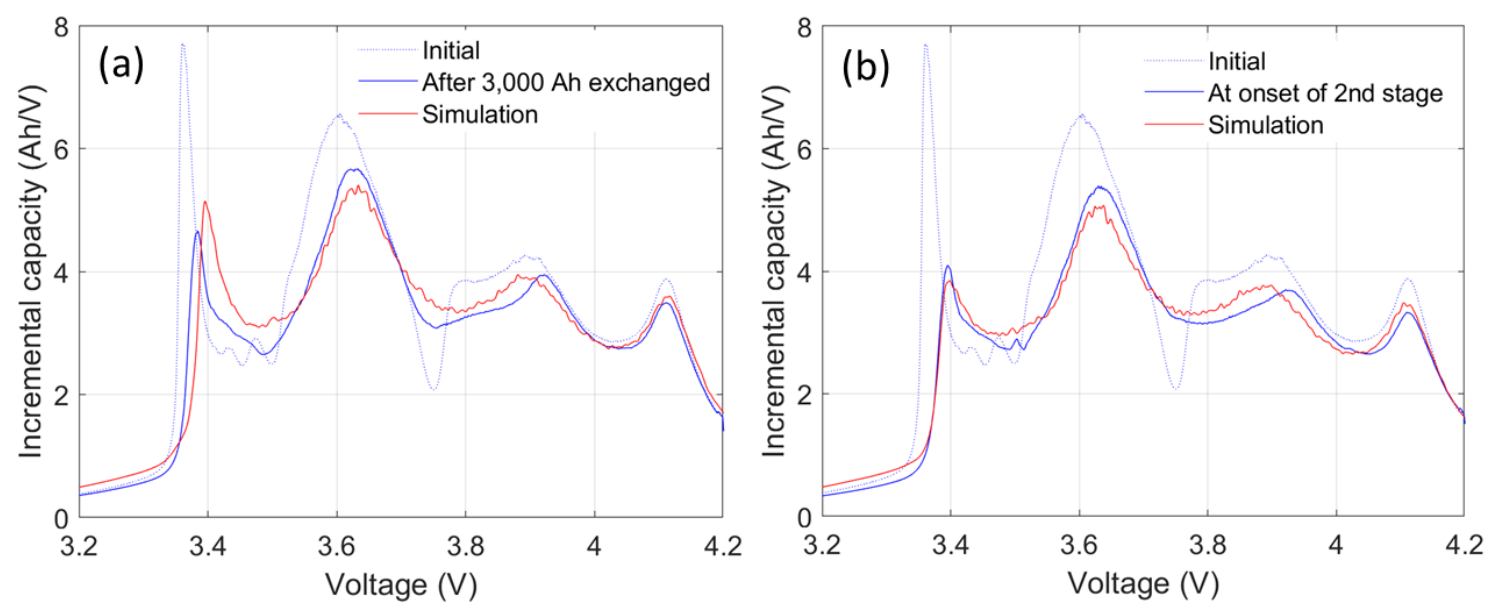

Figure 6. Comparison of experimental and simulated incremental capacity (IC) curves for the NoFR_1 cell (a) after 3000 Ah exchanged and (b) at the onset of the second stage.

\section{Conclusions}

The main takeaway from our study was that some frequency regulation V2G usage at moderate rates (from $C / 5$ to $C / 3$ as a maximum current) did not accelerate the cell degradation despite a close to $15 \%$ additional usage. In addition, there was no noticeable difference between performing this ancillary service during rest or charge or at maximum current fluctuations up to $C / 3$ during rest and $\mathrm{C} / 4$ during charge. These results are extremely positive for the possible application of $\mathrm{V} 2 \mathrm{G} / \mathrm{G} 2 \mathrm{~V}$ strategies. However, it must be noted that our results hold for these specific cells and the duty cycle tested. More research is necessary to generalize the results. Most notably, to test a wide variety of frequency regulation cycles and driving cycles on different cell chemistries. We already verified the results with the same duty cycles on a different batch of commercial cells based on graphite and a blend of lithium cobalt oxide and nickel cobalt aluminum oxide.

Due to the lack of differences in the degradation between duty cycles, the benefits of modulating the charge to eliminate the additional usage on the cells could not be verified. Experiments on other chemistries with more aggressive usages will be launched to test the hypothesis further.

As for the diagnosis for the degradation, a new approach of coupling IC and DV analyses yielded four indicators for automatic diagnosis. This methodology will allow faster diagnosis and bolsters the value of the FOI approach for battery management system implementation. However, our study also showed that, under some conditions-in our case, the apparent kinetic limitations-some of the FOI may become ineffective with time. Therefore, proper validation using full fits and a sensibility analysis to check for the range of efficacy of chosen FOIs is still essential.

Finally, some cells showcased the second stage of aging, and we were not able to predict it from the voltage variations. This suggested that it was not induced by a widespread degradation of the electrodes but was more likely because of localized effects. The cells that did not perform any frequency regulations seemed to be the most affected, but those results need to be moderated by the fact that the differences were probably within what to expect between cells performing the same duty cycles.

Supplementary Materials: The following are available online at http://www.mdpi.com/1996-1073/13/10/2494/s1.

Author Contributions: All the authors designed and performed the experiments, analyzed the results, and wrote the manuscript. All authors have read and agreed to the published version of the manuscript.

Funding: This work was funded by the ONR Asia Pacific Research Initiative for Sustainable Energy Systems, awards No. N00014-16-1-2116 and N00014-17-1-2206. M.D. also has support from the State of Hawai'i. The authors are grateful to the Hawaiian Electric Company for their past support to the operations of the Hawai'i Sustainable Energy Research Facility.

Conflicts of Interest: The authors declare no conflicts of interest. 


\section{References}

1. Lee, T.; Glick, M.B.; Lee, J.-H. Island energy transition: Assessing Hawaii's multi-level, policy-driven approach. Renew. Sustain. Energy Rev. 2020, 118, 109500. [CrossRef]

2. Wee, S.; Coffman, M.; La Croix, S. Do electric vehicle incentives matter? Evidence from the 50 U.S. states. Res. Policy 2018, 47, 1601-1610. [CrossRef]

3. Coffman, M.; Bernstein, P.; Wee, S. Electric vehicles revisited: A review of factors that affect adoption. Transp. Rev. 2016, 37, 79-93. [CrossRef]

4. Kempton, W.; Letendre, S.E. Electric vehicles as a new power source for electric utilities. Transp. Res. Part D Transp. Environ. 1997, 2, 157-175. [CrossRef]

5. Raustad, R. The Role of V2G in the Smart Grid of the Future. Interface 2015, 24, 53-60. [CrossRef]

6. Babrowski, S.; Heinrichs, H.; Jochem, P.; Fichtner, W. Load shift potential of electric vehicles in Europe. J. Power Sources 2014, 255, 283-293. [CrossRef]

7. Honarmand, M.; Zakariazadeh, A.; Jadid, S. Optimal scheduling of electric vehicles in an intelligent parking lot considering vehicle-to-grid concept and battery condition. Energy 2013. [CrossRef]

8. Lefeng, S.; Qian, Z.; Yongjian, P. The reserve trading model considering V2G Reverse. Energy 2013, 59, 50-55. [CrossRef]

9. Mwasilu, F.; Justo, J.J.; Kim, E.-K.; Do, T.D.; Jung, J.-W. Electric vehicles and smart grid interaction: A review on vehicle to grid and renewable energy sources integration. Renew. Sustain. Energy Rev. 2014, 34, 501-516. [CrossRef]

10. Talebizadeh, E.; Rashidinejad, M.; Abdollahi, A. Evaluation of plug-in electric vehicles impact on cost-based unit commitment. J. Power Sources 2014, 248, 545-552. [CrossRef]

11. Zhou, C. Modeling of the Cost of EV BatteryWear Due to V2G Application in Power Systems. IEEE Trans. Energy Convers. 2011, 26, 1043-1050. [CrossRef]

12. Zhang, L.; Jabbari, F.; Brown, T.; Samuelsen, S. Coordinating plug-in electric vehicle charging with electric grid: Valley filling and target load following. J. Power Sources 2014, 267, 584-597. [CrossRef]

13. White, C.D.; Zhang, K.M. Using vehicle-to-grid technology for frequency regulation and peak-load reduction. J. Power Sources 2011, 196, 3972-3980. [CrossRef]

14. Nykvist, B.; Nilsson, M. Rapidly falling costs of battery packs for electric vehicles. Nat. Clim. Chang. 2015, 5, 329-332. [CrossRef]

15. Aziz, M.; Oda, T.; Mitani, T.; Watanabe, Y.; Kashiwagi, T. Utilization of Electric Vehicles and Their Used Batteries for Peak-Load Shifting. Energies 2015, 8, 3720-3738. [CrossRef]

16. Zhao, Y.; Tatari, O. A hybrid life cycle assessment of the vehicle-to-grid application in light duty commercial fleet. Energy 2015, 93, 1277-1286. [CrossRef]

17. Thompson, A.W.; Perez, Y. Vehicle-to-Everything (V2X) energy services, value streams, and regulatory policy implications. Energy Policy 2019. [CrossRef]

18. Bañol Arias, N.; Hashemi, S.; Andersen, P.B.; Træholt, C.; Romero, R. Assessment of economic benefits for EV owners participating in the primary frequency regulation markets. Int. J. Electr. Power Energy Syst. 2020, 120. [CrossRef]

19. Uddin, K.; Dubarry, M.; Glick, M. The viability of vehicle-to-grid operations from a battery technology and policy perspective. Energy Policy 2018, 113, 342-347. [CrossRef]

20. Saldaña, G.; San Martin, J.I.; Zamora, I.; Asensio, F.J.; Oñederra, O. Electric Vehicle into the Grid: Charging Methodologies Aimed at Providing Ancillary Services Considering Battery Degradation. Energies 2019, 12, 2443. [CrossRef]

21. Guo, J.; Yang, J.; Lin, Z.; Serrano, C.; Cortes, A.M. Impact Analysis of V2G Services on EV Battery Degradation-A Review. In Proceedings of the 2019 IEEE Milan PowerTech, Milan, Italy, 23-27 June 2019.

22. Alshahrani, S.; Khalid, M.; Almuhaini, M. Electric Vehicles Beyond Energy Storage and Modern Power Networks: Challenges and Applications. IEEE Access 2019, 7, 99031-99064. [CrossRef]

23. Bishop, J.D.K.; Axon, C.J.; Bonilla, D.; Tran, M.; Banister, D.; McCulloch, M.D. Evaluating the impact of V2G services on the degradation of batteries in PHEV and EV. Appl. Energy 2013, 111, 206-218. [CrossRef]

24. Uddin, K.; Jackson, T.; Widanage, W.D.; Chouchelamane, G.; Jennings, P.A.; Marco, J. On the possibility of extending the lifetime of lithium-ion batteries through optimal V2G facilitated by an integrated vehicle and smart-grid system. Energy 2017, 133, 710-722. [CrossRef] 
25. Dubarry, M.; Devie, A.; McKenzie, K. Durability and reliability of electric vehicle batteries under electric utility grid operations: Bidirectional charging impact analysis. J. Power Sources 2017, 358, 39-49. [CrossRef]

26. Dubarry, M.; Baure, G.; Devie, A. Durability and Reliability of EV Batteries under Electric Utility Grid Operations: Path Dependence of Battery Degradation. J. Electrochem. Soc. 2018, 165, A773-A783. [CrossRef]

27. Marongiu, A.; Roscher, M.; Sauer, D.U. Influence of the vehicle-to-grid strategy on the aging behavior of lithium battery electric vehicles. Appl. Energy 2015, 137, 899-912. [CrossRef]

28. Guo, J.; Yang, J.; Cao, W.; Serrano, C. Evaluation of EV battery degradation under different charging strategies and V2G schemes. In Proceedings of the 8th Renewable Power Generation Conference (RPG 2019), Shanghai, China, 24-25 October 2019.

29. Dubarry, M.; Baure, G.; Anseán, D. Perspective on State-of-Health Determination in Lithium-Ion Batteries. J. Electrochem. Energy Convers. Storage 2020, 17, 1-25. [CrossRef]

30. Frisco, S.; Kumar, A.; Whitacre, J.F.; Litster, S. Understanding Li-Ion Battery Anode Degradation and Pore Morphological Changes through Nano-Resolution X-ray Computed Tomography. J. Electrochem. Soc. 2016, 163, A2636-A2640. [CrossRef]

31. Ansean, D.; Dubarry, M.; Devie, A.; Liaw, B.Y.; Garcia, V.M.; Viera, J.C.; Gonzalez, M. Operando lithium plating quantification and early detection of a commercial $\mathrm{LiFePO} 4$ cell cycled under dynamic driving schedule. J. Power Sources 2017, 356, 36-46. [CrossRef]

32. Gering, K.L.; Sazhin, S.V.; Jamison, D.K.; Michelbacher, C.J.; Liaw, B.Y.; Dubarry, M.; Cugnet, M. Investigation of path dependence in commercial lithium-ion cells chosen for plug-in hybrid vehicle duty cycle protocols. J. Power Sources 2011, 196, 3395-3403. [CrossRef]

33. Burns, J.C.; Kassam, A.; Sinha, N.N.; Downie, L.E.; Solnickova, L.; Way, B.M.; Dahn, J.R. Predicting and Extending the Lifetime of Li-Ion Batteries. J. Electrochem. Soc. 2013, 160, A1451-A1456. [CrossRef]

34. Bloom, I.; Christophersen, J.; Gering, K. Differential voltage analyses of high-power lithium-ion cells 2. Applications. J. Power Sources 2005, 139, 304-313. [CrossRef]

35. Dubarry, M.; Svoboda, V.; Hwu, R.; Liaw, B.Y. Incremental capacity analysis and close-to-equilibrium OCV measurements to quantify capacity fade in commercial rechargeable lithium batteries. Electrochem. Solid State Lett. 2006, 9, A454-A457. [CrossRef]

36. Devie, A.; Dubarry, M. Durability and Reliability of Electric Vehicle Batteries under Electric Utility Grid Operations. Part 1: Cell-to-Cell Variations and Preliminary Testing. Batteries 2016, 2, 28. [CrossRef]

37. Baure, G.; Dubarry, M. Synthetic vs. Real Driving Cycles: A Comparison of Electric Vehicle Battery Degradation. Batteries 2019, 5, 42. [CrossRef]

38. Dubarry, M.; Berecibar, M.; Devie, A.; Anseán, D.; Omar, N.; Villarreal, I. State of health battery estimator enabling degradation diagnosis: Model and algorithm description. J. Power Sources 2017, 360, 59-69. [CrossRef]

39. Berdichevsky, G.K.K.; Straubel, J.B.; Toomre, E. The Tesla Roadster Battery System. Tesla Mot. 2007, 1, 1-5.

40. Uitz, M.; Sternad, M.; Breuer, S.; Täubert, C.; Traußnig, T.; Hennige, V.; Hanzu, I.; Wilkening, M. Aging of Tesla's 18650 Lithium-Ion Cells: Correlating Solid-Electrolyte-Interphase Evolution with Fading in Capacity and Power. J. Electrochem. Soc. 2017, 164, A3503-A3510. [CrossRef]

41. Dubarry, M.; Baure, G. Perspective on Commercial Li-ion Battery Testing, Best Practices for Simple and Effective Protocols. Electronics 2020, 9, 152. [CrossRef]

42. Stein, K.; Tun, M.; Musser, K.; Rocheleau, R. Evaluation of a 1 MW, 250 kW-hr Battery Energy Storage System for Grid Services for the Island of Hawaii. Energies 2018, 11, 3367. [CrossRef]

43. Stein, K.; Tun, M.; Matsuura, M.; Rocheleau, R. Characterization of a Fast Battery Energy Storage System for Primary Frequency Response. Energies 2018, 11, 3358. [CrossRef]

44. Dubarry, M.; Devie, A.; Stein, K.; Tun, M.; Matsuura, M.; Rocheleau, R. Battery Energy Storage System battery durability and reliability under electric utility grid operations: Analysis of 3 years of real usage. J. Power Sources 2017, 338, 65-73. [CrossRef]

45. Dubarry, M.; Truchot, C.; Liaw, B.Y. Synthesize battery degradation modes via a diagnostic and prognostic model. J. Power Sources 2012, 219, 204-216. [CrossRef]

46. Barai, A.; Uddin, K.; Dubarry, M.; Somerville, L.; McGordon, A.; Jennings, P.; Bloom, I. A comparison of methodologies for the non-invasive characterisation of commercial Li-ion cells. Progr. Energy Combust. Sci. 2019, 72, 1-31. [CrossRef] 
47. Dubarry, M.; Devie, A.; Liaw, B.Y. The Value of Battery Diagnostics and Prognostics. J. Energy Power Sources 2014, 1, 242-249.

48. Bloom, I.; Jansen, A.N.; Abraham, D.P.; Knuth, J.; Jones, S.A.; Battaglia, V.S.; Henriksen, G.L. Differential voltage analyses of high-power, lithium-ion cells. 1. Technique and Applications. J. Power Sources 2005, 139, 295-303. [CrossRef]

49. Keil, P.; Jossen, A. Calendar Aging of NCA Lithium-Ion Batteries Investigated by Differential Voltage Analysis and Coulomb Tracking. J. Electrochem. Soc. 2017, 164, A6066-A6074. [CrossRef]

50. Liu, P.; Wang, J.; Hicks-Garner, J.; Sherman, E.; Soukiazian, S.; Verbrugge, M.; Tataria, H.; Musser, J.; Finamore, P. Aging Mechanisms of LiFePO4 Batteries Deduced by Electrochemical and Structural Analyses. J. Electrochem. Soc. 2010, 157, A499-A507. [CrossRef]

51. Honkura, K.; Honbo, H.; Koishikawa, Y.; Horiba, T. State Analysis of Lithium-Ion Batteries Using Discharge Curves. ECS Trans. 2008, 13, 61-73.

52. Dahn, H.M.; Smith, A.J.; Burns, J.C.; Stevens, D.A.; Dahn, J.R. User-Friendly Differential Voltage Analysis Freeware for the Analysis of Degradation Mechanisms in Li-Ion Batteries. J. Electrochem. Soc. 2012, 159, A1405-A1409. [CrossRef]

53. Pastor-Fernández, C.; Yu, T.F.; Widanage, W.D.; Marco, J. Critical review of non-invasive diagnosis techniques for quantification of degradation modes in lithium-ion batteries. Renew. Sustain. Energy Rev. 2019, 109, 138-159. [CrossRef]

54. Kassem, M.; Delacourt, C. Postmortem analysis of calendar-aged graphite/LiFePO4 cells. J. Power Sources 2013, 235, 159-171. [CrossRef]

55. Schmidt, J.P.; Tran, H.Y.; Richter, J.; Ivers-Tiffee, E.; Wohlfahrt-Mehrens, M. Analysis and prediction of the open circuit potential of lithium-ion cells. J. Power Sources 2013, 239, 696-704. [CrossRef]

56. Birkl, C.R.; Roberts, M.R.; McTurk, E.; Bruce, P.G.; Howey, D.A. Degradation diagnostics for lithium ion cells. J. Power Sources 2017, 341, 373-386. [CrossRef]

57. Baumhöfer, T.; Brühl, M.; Rothgang, S.; Sauer, D.U. Production caused variation in capacity aging trend and correlation to initial cell performance. J. Power Sources 2014, 247, 332-338. [CrossRef]

58. Harris, S.J.; Harris, D.J.; Li, C. Failure statistics for commercial lithium ion batteries: A study of 24 pouch cells. J. Power Sources 2017, 342, 589-597. [CrossRef]

59. Rohr, S.; Müller, S.; Baumann, M.; Kerler, M.; Ebert, F.; Kaden, D.; Lienkamp, M. Quantifying Uncertainties in Reusing Lithium-Ion Batteries from Electric Vehicles. Procedia Manuf. 2017, 8, 603-610. [CrossRef]

60. Devie, A.; Baure, G.; Dubarry, M. Intrinsic Variability in the Degradation of a Batch of Commercial 18650 Lithium-Ion Cells. Energies 2018, 11, 1031. [CrossRef]

61. Petz, D.; Mühlbauer, M.J.; Baran, V.; Frost, M.; Schökel, A.; Paulmann, C.; Chen, Y.; Garcés, D.; Senyshyn, A. Lithium heterogeneities in cylinder-type Li-ion batteries_fatigue induced by cycling. J. Power Sources 2019. [CrossRef]

62. Fath, J.P.; Dragicevic, D.; Bittel, L.; Nuhic, A.; Sieg, J.; Hahn, S.; Alsheimer, L.; Spier, B.; Wetzel, T. Quantification of aging mechanisms and inhomogeneity in cycled lithium-ion cells by differential voltage analysis. J. Energy Storage 2019, 25. [CrossRef]

(C) 2020 by the authors. Licensee MDPI, Basel, Switzerland. This article is an open access article distributed under the terms and conditions of the Creative Commons Attribution (CC BY) license (http://creativecommons.org/licenses/by/4.0/). 